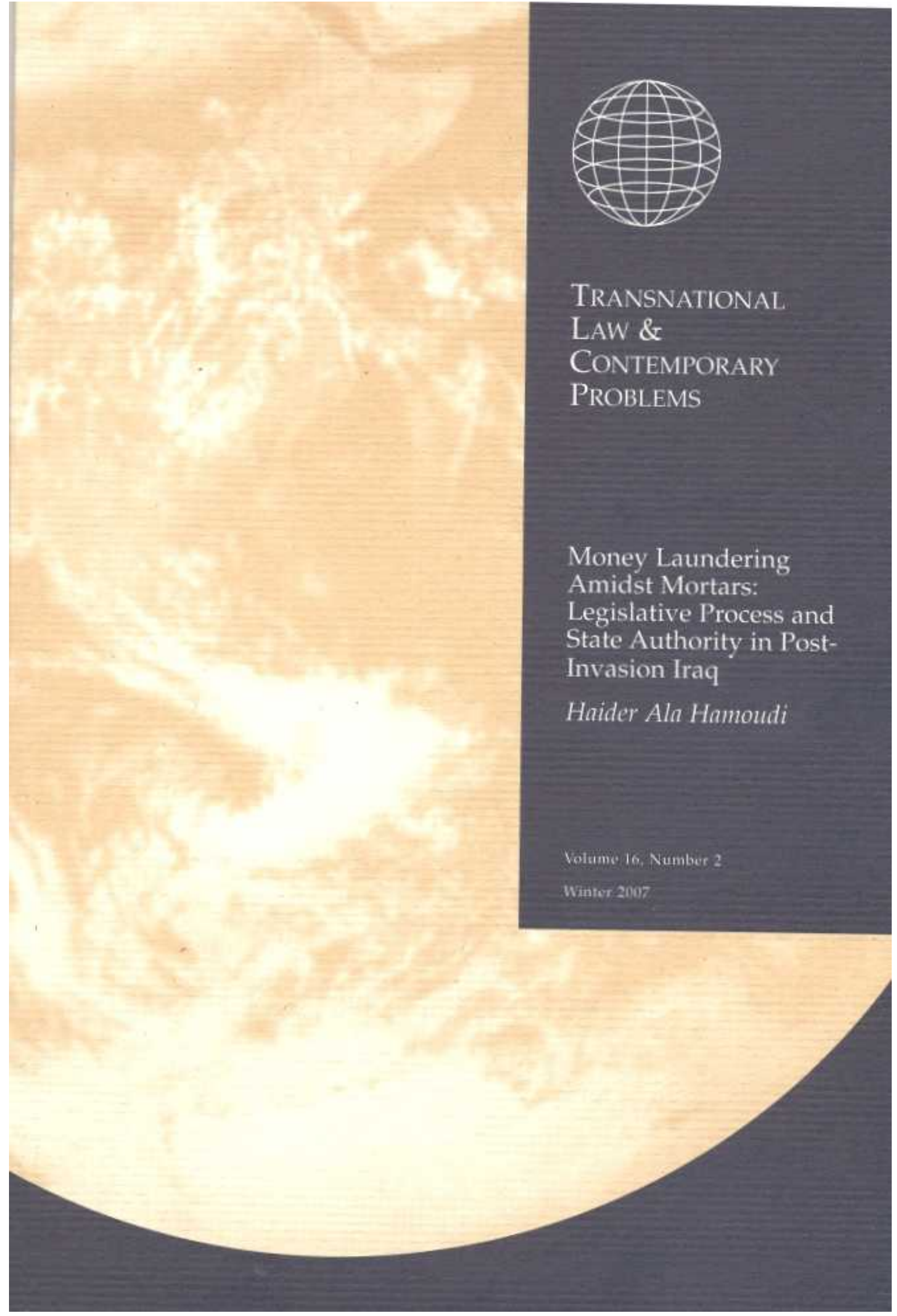




\title{
Money Laundering Amidst Mortars: Legislative Process and State Authority in Post-Invasion Iraq
}

\author{
Haider Ala Hamoudi*
}

I. GeNERAL PRINCIPLES OF LEGAL AUTHORITY

IN IRAQ: MAY 2003-JUNE 28, 2004

II. ORDER 93 AND ECONOMIC GOVERNANCE.

A. Context of Enactment.

B. Aftermath of Enactment

III. The Nature of Non-Legal AUthority

WITHIN THE IRAQI STATE

A. Non-Legal Authority and the Role of the Marja'iyya

B. Disregard of Iraq's Context in Current Literature

IV. Alternative APPROACHES IN THE DEVELOPMENT OF LEGAL AND ECONOMIC ORDER

V. The Problem of Personal Status LaW 543

There is much truth to the common criticism that the Coalition Provisional Authority (CPA)-the U.S.-and U.K.-run entity responsible for

\footnotetext{
* Associate in Law, Columbia Law School. The author served as a legal adviser to the Finance Committee of the Governing Council of Iraq from January 2004 until its dissolution on June 28, 2004. He also acted in a variety of capacities within Iraq from June 2003 until August 2005, primarily in the areas of improvement of Iraqi legal education and the educational methodologies employed in Iraqi law schools. Since leaving Iraq in August 2005, he has worked with and advised various Iraqi entities and individuals, including the Iraq Constitutional Committee, the Office of the Vice Presidency, and Jubilee Iraq. The author would like to thank Adil AbdulMahdi, Hussein Adhab, Justin Alexander, Judge Rizgar Amin, M. Cherif Bassiouni, Ahmed Chalabi, Salem Chalabi, Sheikh Humam Hamoudi, Feisal Isterabadi, Judge Latif AbdulRahman, Adnan Pachachi, and Fareed Yasseen for comments, suggestions, and help in providing information and opportunities critical to the development of this Article. Special thanks to Abdullahi An-Naim, Hoi Kong, and Clark Lombardi for their extensive thoughts and contributions. Any errors are those of the author. Unless otherwise noted, all translations are the author's.
} 
governing Iraq from May 2003 until June 28, 20041-was entirely removed from the concerns of ordinary Iraqis and was, therefore, ineffective in addressing the problems facing Iraq. ${ }^{2}$ However, while the superficial deficiencies of CPA officials in this regard were entirely obvious, the role of these deficiencies in the development of legislation in Iraq has been exaggerated. The more serious structural problem that the CPA faced was a deep disparity between it and the Iraqi authoritative body representing the Iraqi body politic, the Governing Council of Iraq (GC). ${ }^{3}$ The disparity centered on fundamental ideological and ethical assumptions, presuppositions, and biases underlying political and economic forms of human association. This disparity made effective cooperative governance between the CPA and the GC entirely impossible in many instances.

The disparate biases and presuppositions in question specifically relate to the relationship of state authority and law to alternative religious and culturally based sources of authority within the social construct. The most important Iraqi assumption has been that central religious and cultural forms of authority-and in particular the extremely powerful Shi'i religious institution known as the marja'iyya-are not political. Therefore, any matters that are to be governed pursuant to religious rules and norms are properly the province of the marjäiyya and should be largely removed from state control. Given this, any prescriptive ideas respecting legal change in

1 See George PACKer, THE ASSASSINS' GATE: AMERICA IN IRAQ 126 (2005) (concerning the start of CPA rule). Under Security Council Resolution 1546, the CPA was to transfer sovereignty to an interim Iraqi government on June 30, 2004. S.C. Res. 1546, Iף1-2, 4, U.N. Doc. S/RES/1546 (June 7, 2004). For security reasons, however, the actual transfer took place two days earlier, on June 28. PACKER, supra at 332.

2 See Larry Diamond, Squandered Victory: The American Occupation and the Bungled EFFORT TO BRING DEMOCRACY TO IRAQ $297-98$ (2005); William Langewiesche, Welcome to the Green Zone, 294 ATL. MonTHLY, Nov. 1, 2004, at 60; Scott Johnson et al., Lost in the Green Zone, NewsweeK, Sept. 20, 2004, at 33; Lawrence F. Kaplan, Baghdad Dispatch: End of Days, THE NEW REPUBLIC, July 5, 2004, at 12; PACKER, supra note 1, at 180-218.

3 This generalization of attributing the perspective of the entire body politic to one governing body is somewhat reductive, particularly on the part of Iraqis. Many of the Iraqis deeply involved in transitional governance were exiles who had spent the majority of their lives in the United States and Europe, and in two prominent cases, were educated in United States law schools. See, e.g., DIAMOND, supra note 2, at 143-53 (discussing the roles of Salem Chalabi and Feisal Istrabadi, graduates of Northwestern Law School and Indiana Law School, respectively, as the primary Iraqi representatives involved in the drafting of the Transitional Administrative Law). The same charge might well be made against me, as an Iraqi representative serving on the Governing Council's (GC) Finance Committee. None of this, however, is directly relevant to the central thesis of this Article. Clearly some of the representatives on the Iraqi side shared many American presuppositions and biases concerning political and economic rule. Moreover, as Part IV infra makes clear, in select areas, including amendment of the Personal Status Law, a significant number of the GC's members were more sympathetic to CPA concerns than was reflected in the particular stance of the GC. Nevertheless, as this Article shows, the areas of divergence between the CPA and broad swaths of the Iraqi population, as reflected by the GC at times, are extremely significant in understanding the limitations of the CPA's abilities to govern Iraq effectively. 
Iraq, including those developed in this Article, require significant accommodation to Iraqi biases and presuppositions concerning the role of the state in ensuring social order.

By contrast, existing academic literature replicates many of the misconceptions of the CPA by disregarding the particular Iraqi biases toward state authority and the role of the marjaiyya in ensuring social order. ${ }^{4}$ Instead, the current literature gives undue attention to the ways in which religious and cultural norms might be manifested in legal texts and in expressions of political power. ${ }^{5}$ It thereby neglects the manner in which these same norms result in the creation of a landscape of social order wherein the relative authority of the legal texts, and the state organs and institutions responsible for enforcing them, would be less pronounced. ${ }^{6}$ The result has been misplaced analogies to nations with different cultural traditions ${ }^{7}$ and odd assumptions regarding the exercise of religious authority by state organs in a manner hardly contemplated by the Iraqi body politic. ${ }^{8}$ Prescriptive approaches in the literature are therefore necessarily reductive and incomplete.

This Article illustrates this thesis by using a CPA order concerning money laundering (Order 93), the terms of which I participated in negotiating, where Iraqi presuppositions and biases were reflected in GC objections to CPA proposals regarding preferred modalities of regulation and enforcement. 9

This Article is divided into five parts. Part I provides a brief background of the formal legal authority of the CPA and the GC in Iraq following the fall of the Saddam Hussein regime and explains how the bodies were expected to work in principle. Part II highlights the significant disagreement between the $\mathrm{GC}$ and the CPA over financial and economic regulation in the context of Order 93 and shows how this disagreement relates to fundamentally disparate religious, cultural, and ethical assumptions surrounding the

${ }^{4}$ See infra Part III.B.

${ }^{5}$ Id.

${ }^{6} I d$.

${ }^{7}$ See infra notes $72-75$ and accompanying text.

${ }^{8}$ See infra notes 76-84 and accompanying text.

9 See infra Part V. Other, more dramatic examples are available as well, including highly publicized and widely misunderstood attempts by Iraqi legislative institutions, some democratically elected, to repeal the Personal Status Law governing such matters as marriage, divorce, inheritance, and child custody. This Article discusses the Personal Status Law only briefly, as it will be discussed more extensively in a forthcoming article that deals much more directly with the present and future role of Shi'i religious institutions in the development of legal order in contemporary Iraq. 
exercise of regulatory authority and enforcement. Part II also discusses the aftermath of the passage of Order 93 and demonstrates that, while the CPA's formal legal authority may have resulted in its ability to impose its will, the long-term sustainability of the CPA's victories is under assault. Part III examines more deeply the nature and causes of Iraq's disparate biases and assumptions and shows how the academic literature misunderstands Iraq in much the same way that the CPA did. Part IV introduces ideas regarding the means by which Iraq's peculiar biases can, to some extent, be accommodated in the context of financial regulation in order to develop more salutary forms of regulatory control. Finally, Part V touches briefly upon how much of this debate is replicated to much more significant effect in the context of the proposed repeal of the Personal Status Law. There, the debate directly confronts the issue of the exercise of rulemaking authority normally reserved to the states by independent cultural and religious institutions unconstrained by state processes.

\section{GENERAL PRINCIPLES OF LEGAL AUTHORITY IN IRAQ: MAY 2003-JUNE 28, 2004}

On January 20, 2003, prior to the invasion of Iraq, President Bush signed National Security Presidential Directive 24, giving control over post-war Iraq to the Department of Defense and establishing the Office of Reconstruction and Humanitarian Assistance (ORHA), which was to be responsible for administering Iraq after the fall of the regime. ${ }^{10}$ ORHA, however, did not survive much longer than the Saddam Hussein regime itself, which fell in early April, 2003.11 In May, 2003, when it became clear to the United States that significantly greater American involvement in Iraqi political rebuilding would be necessary than was originally conceived, President Bush announced that former diplomat L. Paul Bremer III would succeed the head of ORHA, Jay Garner. ${ }^{12}$ In June of 2003, the Bush administration dissolved ORHA, created the CPA, gave the CPA supreme administrative authority over Iraq on behalf of the United States and the United Kingdom, and named Bremer the U.S. "Ambassador" to Iraq. ${ }^{13}$ Around the same time, on May 22, 2003, the United Nations Security Council issued Resolution 1483, which called upon the United States and the United Kingdom, through the CPA (referred to in the Resolution as the "Authority"), to "promote the welfare of the Iraqi people through effective administration of the territory" in a manner "consistent

10 See PACKER, supra note 1 , at 120.

11 The most common date ascribed to the fall of the Saddam Hussein regime is April 9, 2003, the day that Hussein's statue was toppled in Firdous Square in central Baghdad. See Anthony Shadid, Hussein's Baghdad Falls, WASH. PoST, Apr. 10, 2003, at A1.

12 Packer, supra note 1 , at 144.

${ }^{13} I d$. at 146; DIAMOND, supra note 2, at 13. 
with the Charter of the United Nations and other relevant international law."14 The subsequent paragraph required the CPA to comply with the Geneva Convention and Hague Regulations IV, both of which set forth duties and responsibilities of occupying states. ${ }^{15}$ For example, the Hague Regulations require an occupying state to respect the laws in force in the occupied state "unless absolutely prevented."16

Resolution 1483 also "supported" the efforts of the CPA and the people of Iraq to create an Iraqi "interim administration as a transitional administration run by Iraqis, until an internationally recognized, representative government is established by the people of Iraq and assumes the responsibilities of the Authority." 17 To this end, in July of 2003, the CPA created the "Governing Council" of Iraq (the GC). The GC consisted of twenty-five Iraqis, including some former exiles, to act as the "principal body of the Iraqi interim administration"18 and to consult with the CPA "on all matters involving the temporary governance of Iraq."19 In August of 2003, U.N. Security Council Resolution 1500 formally recognized the GC, "welcom[ing]" its establishment, describing it as "broadly representative," and indicating that its formation was "an important step towards the formation by the people of Iraq of an internationally recognized, representative government that will exercise the sovereignty of Iraq."20 Resolution 1511, passed later that month, acknowledged the GC as the principal body of the interim administration and indicated that the GC "embodie[d]" the sovereignty of Iraq "until an internationally recognized, representative government is established and assumes the responsibilities of the CPA."21

This patchwork of Security Council resolutions and CPA regulations has led to two primary areas of discussion in the academic literature. The first, irrelevant for the purposes of this Article, concerns the ability of the CPA to engage in activities normally referred to as "nation-building" in light of the

14 S.C. Res. 1483, ๆ 4, U.N. Doc. S/RES/1483 (May 22, 2003).

${ }^{15}$ Id. ๆ 5.

16 Hague Convention IV art. 43, Oct. 18, 1907, 36 Stat. 2277, T.S. No. 539.

17 S.C. Res. 1483, supra note 14 , I 9.

18 Coalition Provisional Authority Regulation No. 6, Governing Council of Iraq, pmbl., July 13, 2003.

${ }^{19}$ Id. I 2(1); PACKER, supra note 1, at 212.

${ }^{20}$ S.C. Res. 1500, ๆ 1, U.N. Doc. S/RES/1500 (Aug. 14, 2003).

2 S.C. Res. 1511, ๆ 4, U.N. Doc. S/RES/1511 (Oct. 16, 2003). 
fact that Resolution 1483 limited the powers of the CPA to those held by an occupier under the Hague Convention IV and the Geneva Convention. ${ }^{22}$ The second area of discussion relates to the relative power of the GC vis-à-vis the CPA under the various resolutions. Using the U.N. resolutions, contemporaneous statements of world leaders, and other U.S. and foreign government documentation, Thomas Grant has argued thoughtfully that the intention of these resolutions was to transfer power incrementally from the CPA to the GC, with the U.N. playing a significant advisory role. ${ }^{23}$ Grant writes that as public order was restored and strengthened, the GC would assume increasing power, with temporary regressions in the event of setbacks in security, until the GC ultimately transferred power to a legitimate sovereign Iraq. ${ }^{24}$

Grant's work was published in 2003, and it is somewhat out of date. The role he expected the United Nations to play did not materialize following the bombing of its headquarters in August 2003.25 Moreover, to the extent that Grant is correct that setbacks in public security would result in a strengthening of the CPA's position of authority, the catastrophic failure of the United States to establish security in Iraq would suggest that primary authority would remain with the CPA throughout its existence. As Gregory Fox properly notes, this is precisely what happened, with "Ambassador" Bremer effectively holding a veto over GC-initiated legislation, ${ }^{26}$ and CPA staff, acting as "advisors" to the various Iraqi ministries, exercising final, authoritative control over those ministries. ${ }^{27}$ Moreover, while Resolutions

\footnotetext{
22 Much of this debate arose in the context of CPA Order 39, which as a formal legal matter turned Iraq from one of the most investor-hostile nations on earth to one of the most investorfriendly. CPA Order 39 (Sept. 19, 2003). The consensus appears to be that legislation of this sort is a clear violation of Hague Convention IV, and by extension, Resolution 1483. See, e.g., David J. Scheffer, Beyond Occupation Law, 97 AM. J. INT'L L. 842 (2003); Gregory H. Fox, The Occupation of Iraq, 36 GEO. J. INT'L L. 195, 232-46 (2005); Melissa A. Murphy, Note and Comment, $A$ 'World Occupation" of the Iraqi Economy? How Order 39 Will Create a Semi-Sovereign State, 19 CoNN. J. INT'L L. 445, 457-60 (2004). Cf. Brett H. McGurk, Revisiting the Law of Nation-Building: Iraq in Transition, 43 VA. J. INT'L L. 451 (2005) (former CPA Associate General Counsel indicating that CPA Orders adhered to Resolution 1483 and the "spirit" of Hague Convention IV and the Geneva Convention).

${ }^{23}$ See Thomas D. Grant, The Security Council and Iraq: An Incremental Practice, 97 AM. J. INT'L L. 823, 825 (2003).

${ }^{24} I d$.

25 Grant mentions the bombing and the U.N. determination to continue its role in Iraq notwithstanding. Id. at $\mathbf{8 3 2}$. However, his article was published before the deteriorating security situation effectively prevented the U.N. from establishing a subsequent, meaningful presence in Iraq.

${ }^{26}$ See Fox, supra note 22, at 206.

27 Id. at 252 .
} 
1483, 1500, and 1511 refer to an Iraqi body acting as an "interim administration," they qualify this with an indication that this body will cease to exist when a sovereign Iraqi government assumes the powers of the CPA. This seems to suggest that the powers given to the GC by the Security Council, while unspecified, were not equivalent to those of the CPA. Therefore, it was reasonably clear that the CPA would be the ultimate arbiter of administrative governance in Iraq, despite the Orwellian terminology of governing "advisors," an advisory "Governing Council," and a ruling "Ambassador."

Semantics aside, however, a deeper question of legitimacy remains. The CPA was aware that it probably would be unable to affect sweeping change in Iraq's political, administrative, and economic order without the support of Iraqi ministries and other governmental and administrative institutions. ${ }^{28}$ It is therefore simplistic and inaccurate to suggest that the GC had no role in governance and was created cynically by the CPA to demonstrate Iraqi support for CPA actions. In my negotiations with CPA personnel while serving on the GC's Finance Committee, the CPA gave GC views consideration; the GC was even successful at delaying the approval of some pieces of critical legislation when it voiced significant opposition to GC proposals. In my experience, the parties on all sides made compromises on many questions.

Moreover, and more importantly, the selection of the GC members hardly supports the claim that the CPA sought nothing more than a "rubber stamp." GC members were chosen with the assistance of the United Nations. ${ }^{29}$ Those chosen were, with some exception, clearly leaders of their respective ethnic and sectarian communities and were, broadly speaking, representative of the Iraqi population. Among the Governing Council Members were Jalal Talabani and Mas'ud Barazani, the leaders of the two dominant Kurdish political parties in Iraq, whose alliance won fifty-three of 275 seats in the last Iraqi election; Abdul Aziz al Hakim and Ibrahim al-Ja'fari, the two most prominent leaders of the United Iraqi Alliance, the dominant Shi'i organization, which won 128 seats in the last election;30 Ayad Allawi, the former Prime Minister, and Adnan Pachachi, whose secular, nationalist, and nonsectarian alliance won twenty-five seats in the last election; and the

${ }^{28}$ See, e.g., infra note 58 (discussing this phenomenon in a broader context).

29 See PACKER, supra note 1, at 212.

${ }^{30}$ Admittedly, the United Iraqi Alliance includes a third leader of substantial influence, Moqtada al-Sadr, whose omission from the membership of the Governing Council is probably the most glaring. However, while Sadr was certainly not an unknown at the time the GC was created, his influence rose sharply after its creation during a rebellion, in April 2004, that his followers led throughout southern Iraq. Rod Nordland, The Iraqi Intifada, NEWSWEEK: WEB EXCLUSIVE, Apr. 10, 2004, http://msnbc.msn.com/id/4710176/ (describing Sadr prior to the April uprising with some exaggeration as "a nobody with a couple of thousand armed followers"). 
Sunni Arab leader Mohsen Abdul Hameed, former head of the Iraqi Islamic Party, whose party was a central part of the Sunni alliance that won fortyfour seats in the last election. ${ }^{31}$ It is therefore difficult to sustain the claim that the GC was not substantially representative of Iraq. Had the CPA simply been looking for any Iraqi authority to accept responsibility, it could have created a friendlier, less representative, and more pliant council that would not have raised as many concerns over its orders as the GC did.

Thus, the GC was in fact a competing, although inferior, authoritative body whose role in governance was fundamental if CPA orders were to be implemented meaningfully. As Grant predicted, as the influence of the GC over Iraq's ministries and other regulatory bodies increased, so did its influence over Iraq's policy, albeit to a lesser extent than Grant anticipated. ${ }^{32}$ Cognizant of this influence, the CPA did not fail to consult, and in some cases defer to, the GC as it prepared and issued 100 orders, twelve regulations, seventeen memoranda, and twelve public notices during its tenure. ${ }^{33}$

Nevertheless, the disparity in formal authority affected the interaction between the two bodies concerning the issuance of legislation, usually in the form of CPA Orders. Specifically, while the CPA could effectively block any GC initiatives by simply refusing to issue an order respecting them, the CPA required no such GC approval. ${ }^{34}$ Thus, to avoid a crisis or the appearance of impotency, a GC objection would never take the form of outright rejection if the CPA was insistent enough. Rather, the GC might seek amendments, or, if it was strongly opposed to CPA legislation, simply approve the order without the slightest intention of implementing it. ${ }^{35}$

At times, this system of competing bodies of authority worked well. The most prominent example with which I was involved concerned the

31 See Council on Foreign Relations, Iraq: Iraq's Governing Council, May 17, 2004, http://www.cfr.org/publication/7665/\#15; The Independent Electoral Commission of Iraq, Certification of the Council of Representatives Elections Final Results, Feb. 10, 2006, http://www.ieciraq.org/English (follow "December 15 Results" hyperlink; then follow "Certified Results” hyperlink).

32 On August 31, 2003, the GC, with CPA approval, appointed twenty-five ministers to serve as the Iraqi Cabinet. These Iraqis, drawn largely from the same political entities that composed the GC, would clearly be more responsive to their sponsors within the GC than to the "advisors" of the CPA. See Daniel Williams, Iraqi Council Completes Cabinet: 25 Members Are Selected in Bid to Increase Influence, Exercise More Authority, WASH. POST, Sept. 1, 2003, at A18.

33 See The Coalition Provisional Government, CPA Official Documents, http://www.iraqcoalition.org/regulations/index.html\#Regulations (last visited Jan. 21, 2007).

34 See, e.g., Alyssa J. Rubin, Iraqi Widows Expand Horizons, L.A. TIMES, Feb. 17, 2005, at A5; Salamander Davoudi, Fears for Women's Rights after Handover of Power, Fin. Times, Feb. 27, 2004, at 10 (discussing Ambassador Bremer's effective veto over a Governing Council Resolution respecting family law).

${ }^{35}$ See Infra Part II.B. 
promulgation of Order 43 , respecting the issuance of new forms of currency. ${ }^{36}$ At the time of my arrival in Baghdad in July 2003, Iraqi banknotes were denominated in bills no larger than 250 Iraqi dinars, worth approximately sixteen cents. ${ }^{37}$ The purchase of the most basic groceries required a shopper to carry large, brick-like stacks of bills, neither a convenient nor a safe practice. Moreover, the notes were usually quite worn. The notes were not used in Kurdish-controlled northern Iraq, where Iraqis relied on pre-1990 notes of differing value known commonly as "Swiss" dinars. ${ }^{38}$ Moreover, the legal currency continued to bear the picture of Saddam Hussein, which was dispiriting to the new administrators of Iraq.

Order 43, supported by both the GC and the CPA, ordered the Central Bank of Iraq to issue new notes in denominations of its choice, to be used throughout Iraq. ${ }^{39}$ Order 43 further called for the exchange of both the Swiss dinars and the old notes for the new notes over a three month conversion period, after which the old notes would cease to be legal tender. ${ }^{40}$ The Central Bank of Iraq, whose governor was selected by the GC, supported the Order, and, as a result, the transition was remarkably smooth. ${ }^{41}$ By the end of January 2004, all of Iraq was using the new and more convenient banknotes, with bills ranging in value from fifty dinars, approximately three cents, to 25,000 dinars, or $\$ 16.66$. Even Hanke and Sekerke, who are deeply critical of the CPA's efforts in the area of currency reform, consider the exchange of notes a major success. ${ }^{42}$ Certainly, my experience among Iraqis suggests that they overwhelmingly approved of the CPA and GC efforts in this regard. There are other examples of successful cooperation, most prominent among them the establishment of the human rights and environment ministries,

36 See generally Coalition Provisional Authority Order No. 43, New Iraqi Dinar Banknotes, Oct. $14,2003$.

37 A 10,000 dinar note existed, but its value was discounted more than 30 percent, apparently due to excessive counterfeiting. See Steve Hanke \& Matt Sekerke, Iraq's Botched Currency Reform, 14 CENT. BANK. J. 40, 40 n.1 (2004).

38 See Coalition Provisional Authority Order No. 43, New Iraqi Dinar Banknotes, § 1, Oct. 14, 2003.

${ }^{39} I d$.

${ }^{40} I d . \S \S 2-6$.

41 Iraqi Governing Council Appoints New Central Bank Director, VoICE OF AM. News, Sept. 10, 2003.

${ }^{42}$ Hanke \& Sekerke, supra note 37 , at 40 n.1. 
both generally welcomed by the GC and by Iraqis. ${ }^{43}$ It is, however, those situations in which the system did not work particularly well that best highlight the nature of the CPA's failures in governance.

\section{ORDER 93 AND ECONOMIC GOVERNANCE}

\section{A. Context of Enactment}

During my tenure as a legal adviser on the GC's Finance Committee, few seemingly innocuous orders that came before us caused as much controversy as Order 93, which concerned money laundering. There were orders that generated more acrimony, but for the most part these were on particularly sensitive subjects where one would expect controversy. ${ }^{44}$ The moneylaundering order, much like orders concerning child labor, ${ }^{45}$ anti-corruption, ${ }^{46}$ and amendments to the Company Law, ${ }^{47}$ did not suggest any divergence between the GC and the CPA in the articulation of its objectives. It was clear from discussions that both bodies favored legislation that would limit the ability of terrorist groups to launder money and finance operations within Iraq.

Difficulty arose, however, when I suggested that including ordinary currency exchanges within the scope of the law would be extremely problematic as a practical matter because of the large number of exchanges operating in Iraq. The proposed order defined financial institutions as including "foreign currency exchange houses, or any other entity that effects foreign exchange transactions on a regular basis above $[\$ 10,000] . " 48$ I suggested excluding the currency exchanges except for those that exchanged over $\$ 100,000$ weekly. Under this proposal, exchanges trading $\$ 10,000$ to

\footnotetext{
43 See generally Coalition Provisional Authority Order No. 144, Establishment of the Ministry of Environment, Nov. 11, 2003 (issued Nov. 24, 2003); Coalition Provisional Authority No. 60, Establishment of the Ministry of Human Rights, Feb. 19, 2004 (issued Feb. 22, 2004).

44 The most prominent examples are Order 39, concerning foreign investment (enacted prior to
my arrival on the Finance Committee) and Order 95, concerning Iraq's debt. See Coalition
Provisional Authority Order No. 39, Foreign Investment, Sept. 19, 2003 (enacted Dec. 20, 2003);
Coalition Provisional Authority Order No. 95, Financial Management Law and Public Debt Law,
June 2, 2004 (enacted June 4, 2004).
}

45 See Coalition Provisional Authority Order No. 89, Amendments to the Labor Code Law No. 71 of 1987, May 5, 2004 (enacted May 30, 2004).

46 See Coalition Provisional Authority Order No. 87, Public Contracts, May 14, 2004 (enacted May 17, 2004).

47 See Coalition Provisional Authority Order No. 64, Amendment to the Company Law No. 21 of 1997, Feb. 14, 2004 (enacted Mar. 5, 2004).

48 See Draft, Coalition Provisional Authority Order No. 93, art. 2, sec. 4f, Apr. 17, 2004 (on file with author). 
$\$ 100,000$ weekly then would be subject to Central Bank regulations to be issued at a later date.

The basic problem was that currency exchange houses had proliferated in Iraq for a variety of reasons, including the need for access to local currency for routine purchases, the Iraqi preference for holding as much money as possible in dollars to avoid any consequences of inflation, and the general lack of suitable alternatives to cash (such as credit cards or bank accounts). By my estimation, there were literally several exchanges at nearly every street corner in Baghdad. I assumed they routinely exchanged more than $\$ 10,000$ a week, given that I would often exchange $\$ 2000$ at a time, and my requests hardly seemed difficult for them to fulfill. Until circumstances permitted the Central Bank to exercise authority over the exchanges sensibly, it seemed highly impractical to expect all such exchange houses to comply with an anti-money-laundering order that would, among other things, require them to keep extensive records of their transactions. ${ }^{49}$

The CPA officers with whom we worked resisted this rather strongly, primarily on the defensible ground that excluding the vast majority of currency exchange houses in Iraq from the ambit of the law would render the law toothless. They argued that money more likely would be laundered in such houses than in banks.

A number of GC delegates, quite surprisingly to me at the time, objected to this CPA characterization on the grounds that currency exchanges were not like banks. They were not greedy, self-serving profit maximizers that engaged in such obscene practices as the taking of interest; rather, they were small businesses, run by reputable and devout businessmen who earned an honest living through trade.50 The Order's opponents accepted that a currency exchange house at some point might engage in nefarious activity, but insisted that, as a general matter, they were more trustworthy, and therefore less in need of regulation, than banks. Moreover, to the extent that exchangers were seriously involved in illicit operations, family members, clan leaders, community elders, and other elements of power not affiliated with

49 See, e.g., Coalition Provisional Authority Order No. 93, Anti-Money Laundering Act of 2004, art. 22, June 2, 2004 [hereinafter "Order 93"].

50 Dr. Ahmed Chalabi, the GC member who served as head of the committee, or a designated appointee (often Hachim Al-Hassani, who later served as Speaker of the Parliament) routinely chaired the Finance Committee meetings. Also attending were Kamel el-Gailani, then Finance Minister; Dr. Sinan Al-Shabibi, the Central Bank Governor; Haider Al-Uzri, the director of Iraq's largest publicly owned bank, the Rafidain; and Hussein Al-Uzri, the head of the Trade Bank of Iraq. In addition, a single representative from each $\mathrm{GC}$ member attended the meetings. It was the representatives of GC members who registered nearly all of the objections to Order 93 discussed here. As these representatives would change from meeting to meeting, and large numbers of absences were not uncommon, it is nearly impossible, despite my extensive notes, to recount precisely which representatives registered which objections, and whom they were representing when making them. 
State control could act as a restraint in lieu of State regulation and enforcement.

CPA officials did not even attempt to address these objections in our initial meeting and seemed to regard them as befuddling. One muttered aloud that it was odd indeed that a Finance Committee member would cast aspersions on the collection of interest. Discussions were vehement and extensive, and forced the draft order to a rare second session of negotiation. ${ }^{51}$ In the second meeting, the CPA agreed to delay implementation by nine months (or to let the Central Bank issue regulations setting an alternative date),,$^{52}$ converted the U.S. dollar figure to dinars ${ }^{53}$ to address the possibility of inflation, and more or less refused to consider other changes. Despite the fact that their concerns hardly had been addressed by these modest changes, GC representatives were unwilling to create a legislative crisis over the proposed order, particularly given that the GC was well aware that whatever the CPA wrote in the order was of little import unless the GC and the Central Bank chose to implement it. ${ }^{54}$ The Finance Committee thus approved the measure on May 20, 2004, and Ambassador Bremer signed it as Order 93 on June 3, 2004. ${ }^{55}$

The CPA refusal to consider seriously the GC objections does not reflect incompetence or political partisanship. Rather, the GC objections seemed to demonstrate two culturally- and religiously-based assumptions of legal order entirely alien to those accustomed to Western forms of economic governance. First, the juristic Muslim prohibition on paying interest had a clear effect on the objectors' visions of the appropriate modalities of regulation in commercial affairs. Shari'a, broadly defined as the body of rules that Islamic jurists developed in accordance with established principles of Islamic jurisprudence, has not played a significant role in the development of the commercial law in Iraq or most of the Islamic world. ${ }^{56}$ The objectors did not

51 The second session was not called solely to address the scope of the law as against currency exchanges. In addition, Dr. Chalabi had rightly objected that the draft order, in its emphasis on detecting funds generated from "unlawful" activities, oddly did not seem to prohibit the laundering of unseemly funds obtained "lawfully" during the Ba'ath era, including funds generated from the sale of property taken forcefully without compensation from citizens on the basis of ethnicity or political affiliation. This problem was addressed in the final version of Order 93. See Order 93, supra note 49, at art. 6(b).

52 Id. at art. 24.

${ }^{53}$ See id. at art 1 , sec. $4 \mathrm{f}$.

54 See infra Part II.B.

55 See Order 93, supra note 49, at art. 26.

${ }^{56}$ Bernard Weiss, for example, properly notes that outside of the realm of family law, shari'a has not continued to play a significant role in the legal codes of most Muslim nations. BERNARD 
seem to want to disturb its role, but to use shari'a to inform the determination of which industries were inherently suspect, and therefore, in need of regulation. Specifically, the common Muslim objection to interest derives largely from Islamic notions of exploitation and unfairness. More than one of the objections to Order 93 contrasted the profit-hungry, interesttaking banks with honest and devout businessmen faithfully earning their wages "at Allah's door," to use the common Iraqi phrase.

The objectors made an underlying assumption that authority over currency exchangers, which were smaller enterprises dominated by presumably more devout individuals, lay beyond the State. From their perspective, it would be more appropriate to use Shari'a-based regulatory control more harmonious with local customs and norms, rather than secular, externally imposed regulations more appropriate for large interest-taking organizations. None of this made sense to the CPA, nor could it. The CPA could hardly be expected to deal with these types of concerns in governing the nation when they violated their most central assumptions concerning what "governance" was supposed to entail.

\section{B. Aftermath of Enactment}

The CPA's formal dominance ensured that it would be able to enact its version of any legislation in the event of conflict with the GC. Ultimately however, the GC was perfectly capable of implicit veto simply by refusing to implement the law. A smaller dispute concerning enactment of amendments to the Labor Code concerning the labor of children made this clear. I had been engaged in a heated dispute with a CPA official concerning the practicality of

WEISS, THE SPIRIT OF ISLAMIC LAW 188 (1988). Iraq has been no exception; its Civil Code was drafted by a relative secularist and the greatest Arab legal scholar of the past century, Abd AlRazzaq Al-Sanhuri. Haider Ala Hamoudi, Muhammad's Social Justice or Muslim Cant: Langdellianism and the Failures of Islamic Finance, 40 CORNELL INT'L L.J. (forthcoming 2007) [hereinafter Hamoudi, Muhammad's Social Justice]. Among other things, the Code clearly permits the taking of interest in personal or commercial arrangements. IRAQ CIV. CODE §§ 171-72 (1951). Islamic parties do not seem to be agitating in favor of amendment of these provisions. In fact, Adel Abdul-Mahdi, a prominent member of one of the Shi'i Islamist parties who led a Shi'i boycott of the GC following its repeal of a resolution imposing Shari'a in matters of family law, negotiated a debt forgiveness package with the Paris Club while serving as Finance Minister that involved reduced but real debt repayment. William Neikirk, Debt Deal is a Boon for Iraq, CHI. TRIB., Dec. 17, 2004, at C19. Mahdi's involvement in this affair, notwithstanding the traditional characterization by Islamists of all interest as exploitative, was particularly ironic because interest earned on Iraq's debt is quite possibly as exploitative a form of gain as might exist in conventional forms of lending practice. Iraq's debt was incurred by a brutal dictator and in many cases the money was used to finance personal projects of no substantial value to the Iraqi population, leading one prominent organization, Jubilee Iraq, to call for the entire cancellation of the nation's debt. See Maysa Ibrahim, MERIP Media Resource List (Sept. 22, 2005), http://www.merip.org/press_room $/ \mathrm{mrl} / \mathrm{mrl} 092205 . h t m l$. Iraq's current President, Jalal Talabani, joined the call, at least with respect to debts incurred to Gulf Arab countries. Iraq Asks Arab States to Cancel Saddam-era Debt, REUTERS, July 5, 2006. This is not meant so much as a criticism of Mahdi, an individual for whom I have developed a great deal of respect, as it is an indication of the extent to which even the wisest Islamists within Iraq have effectively accepted even the least defensible and most controversial principles of global commerce despite their obvious divergence from the rules of Shari'a. 
a provision that exempted family businesses from the Code where the child in question was over fifteen years old. Most businesses in Iraq were small, family-run enterprises which routinely employed children, particularly after school hours. I wondered whether it was more sensible to ensure that children were educated, rather than commit ourselves to enacting legislation that could never be enforced and that could have a severe impact on Iraq's struggling economy if it were.

The CPA official responsible for the legislation maintained that I was advocating a departure from international labor standards and refused to compromise on this point. The acting head of the committee at the time, Hachem Al-Hassani, interjected after some time, and told me that it was best to leave such provisions in the document if the CPA felt strongly about them. Everyone was well aware that no police force could or would close down family enterprises for this kind of violation of the Labor Code, and clearly the CPA did not have the capacity to do it themselves. Moreover, Dr. Al-Hassani continued, the provision articulated a lofty goal to which there was no objection in principle, and leaving it as an empty letter on the books could serve some aspirational value. Sensing no support for my position, I merely registered my concerns in writing to the GC member whom I represented and let the matter rest. Ultimately, the GC passed the amendments to the Labor Code as Order 89, and the family enterprise exception stands in the limited form on which the CPA insisted in Article 96. ${ }^{57}$ Article 96 remains wholly unenforced; family enterprises continue to openly employ children under the age of fifteen without legal consequence. ${ }^{58}$

Order 93 seems to have followed a similar path, at least insofar as currency exchanges are concerned. The Central Bank of Iraq has issued no regulations on money laundering that are publicly available, nor has it sought to assert jurisdiction over currency exchanges. ${ }^{59}$ Moreover, the currency exchangers whom I know personally express shock and outrage at any suggestion that the authority of the Central Bank applies to them, or

57 Coalition Provisional Authority Order No. 89, Amendments to the Labor Code-Law No. 71 of 1987, art. 96, May 5, 2004 (enacted May 30, 2004).

58 The conscious disregard of imposed legislation is not a phenomenon unique to Iraq. Katharina Pistor, for example, has argued forcefully against the standardization of law in the commercial and corporate legal systems of developing nations generally on several grounds, one being that law is a "cognitive institution" and will not be effective unless embraced not only by enforcement institutions, but also by the broader culture within which it operates. Katharina Pistor, The Standardization of Law and Its Effect on Developing Countries, 50 AM. J. COMP. L. 97 (2002). Pistor specifically indicates that law not so embraced might well be ignored and therefore serve no role in affecting behavior. Id. at 112-15.

59 The Central Bank of Iraq has a website with its most recent regulations posted in both English and Arabic. See Central Bank of Iraq, Banking Laws, http:/www.cbiraq.org/cbs3.htm (last visited Oct. 2, 2006). Regulations concerning money laundering do not appear. Moreover, I have continued to exchange currency in Iraqi exchanges through proxies for a variety of projects, and not once has a transaction been recorded by the exchange house as Order 93 requires. 
that they need to keep records to demonstrate the absence of money laundering.

\section{The NATURE OF NON-LEGAL AUTHORITY WITHIN THE IRAQI STATE}

\section{A. Non-Legal Authority and the Role of the Marja'iyya}

Within Iraq, the idea of delegating authority over matters generally subject to state supervision to institutions that operate beyond state control is not as impossible as it might sound. Certainly in my own experience, insurance companies and their attorneys do not settle legal claims resulting from car accidents in Iraq. Instead, the clans or families of those involved settle the claim, setting appropriate compensation levels and demanding they be paid. I never inquired into the consequences of failing to make these payments, which were as a technical, legal matter entirely voluntary, though family members and others assured me that it would be wiser to defy the law than an accord reached by the clans. Other examples appear in media reports. One involved the offer of three women from one tribe to a rival tribe for marriage, along with a payment of $\$ 3,000$, as compensation for murder. ${ }^{60}$ By seeking to exempt currency houses from money laundering legislation, the GC advocates sought to sanction forms of social arrangements that already existed.

Perhaps even more importantly, Shi'i Islam, to which the vast majority of Iraqis living outside of the Kurdish-dominated region of Iraq adhere, ${ }^{61}$ traditionally places the determination of Shari'a with clerics known as mujtahids within an informal and entirely extralegal hierarchy known as the marja'iyya. ${ }^{62}$ The membership of the marja'iyya shifts over time, and the

60 Sabrina Tavernise \& Qais Mizher, In Iraq's Mayhem, Town Finds Calm Through Its Tribal Links, N.Y. TIMES, July 10, 2006, at A5.

61 Shi'i Muslims constitute 60 percent of Iraq's population and 75 to 80 percent of the nonKurdish population. DIAMOND, supra note 2 , at 328 . I have only excluded the Kurds from consideration because they predominate in a northern autonomous region where regional legislation takes precedence over any legislation promulgated by the central government, except with respect to particularly national issues such as foreign affairs and the issuing of currency. IRAQ CONST. art. 115. Effectively, this means that those in the Kurdish region have no real interest in the overwhelming majority of the legislative pronouncements of the central government, including those concerning money laundering or family law. In addition, by not discussing Sunnism, I by no means intend to suggest that the substantial Sunni population is irrelevant; it may very well be the presence of the Sunni population that makes the Iraqi marja'iyya so reluctant to advocate the type of political juristic rule that exists in Iran. See infra note 67 . I only seek to highlight how particular institutional peculiarities of the dominant Shi'a result in Iraqi assumptions and biases, at least among the Shi'a, regarding the relative role of the state in ensuring social order. The academic literature to date, through specious analogies of Iraq to Egypt and the conflation of judicial and juristic function, seems to ignore these unique features of Iraqi Shi'ism, making this exposition doubly important.

62 Haider Ala Hamoudi, You Say You Want a Revolution: Deviationist Doctrine, Constitutional Moments, and the Origins of Islamic Finance, sec. II.B.1, available at 
status and prestige of any actual or aspiring mujtahid depend on a variety of factors, including the number of followers that have voluntarily pledged their support to the mujtahid through a tithe known as khums and the mujtahid's relative reputation among his peers. ${ }^{63}$ The institution is global, as any Shi'i is free to follow any living mujtahid no matter where they might be situated, though one is supposed to continue following the one mujtahid he has selected unless the mujtahid dies or other "legitimate" circumstances warrant a change. ${ }^{64}$ Given that there is no formal process for annointing a mujtahid, there is no certainty of their precise number ${ }^{65}$

The marja'iyya system of rulemaking is entirely incompatible with lawmaking in a modern nation-state.66 The contours of Shari'a are not uniform but shift, in some cases markedly, with respect to any follower who picks his mujtahid from an indeterminate and ever-shifting class. Moreover, the relevant mujtahids might not even be Iraqi citizens or residents, let alone functionaries of the State, rendering their lawmaking capacity even more problematic. Given these realities, most Shi'i Iraqi jurists seem to have taken the position that the marja iyya should not be an institution of political rule. ${ }^{67}$

http://papers.ssrn.com/sol3/papers.cfm?abstract_id=962448 [hereinafter Hamoudi, You Say You Want a Revolution].

${ }^{63} I d$.

64 See, e.g., MuHAMmad BaQIR AL-SADR, AL-FATAWA AL-WAdiHa 21 -26 (1977).

${ }^{65}$ Hamoudi, supra note 62, at sec. II.B.1.

66 Along the same lines, Professor An-Na'im has argued more generally, and compellingly, that Shari'a is, across all relevant schools of thought, a complex normative system of often-conflicting rules developed by jurists of competing schools or jurisprudential trends, none of which is more or less legitimate than any other. This makes its imposition as a matter of positive law conceptually impossible. See, e.g., Abdullahi An-Na'im, Shari'a and Positive Legislation: Is an Islamic State Possible or Viable?, in 5 Y.B. OF ISLAMIC AND MIDDLE EASTERN LAW 1998-1999, 2941 (Eugene Cotran \& Chibli Mallat eds., 1999) [hereinafter YEARBOOK]. The establishment of his claim is unnecessary for purposes of this Article. It suffices to say that, at least within the context of contemporary Iraqi Shi'ism, the marja'iyya does not, and could not in its current form, function as a political or lawmaking institution.

67 Two influential jurists, Muhammad Baqir al-Sadr, a Shi'i Iraqi, and Ruhollah Khomeini, who led the Islamic Revolution, forcefully advocated a political theory known as "guardianship of the jurist," which ensures the political dominance of the marjäiyya by establishing a single "just ruler" under whose authority the marja'iyya operate. CHIBLI MALLAT, THE RENEWAL OF ISLAMIC LAW: Muhammad BaQER AS-SADAR, NAJAF AND THE ShI'L INTERNATIONAL 71-75 (1993). This theory has not been widely accepted among the senior members of the marja'iyya in Iraq, nor is the type of Islamic state it suggests supported, at least openly, by Iraq's Islamist parties. The late Grand Ayatollah Khoo'ei, for example, has indicated with thinly disguised sarcasm that "guardianship of the jurist" was indeed part of shari'a, and that it referred to the right of a religious scholar to act in loco parentis with respect to an orphan. ABU QASIM IBN ALI AKBAR ALKHOO'EI, S.IRAT. AL-NAJAH FI AJWIBAT AL-ISTIFTAAT 10 (1995). The current most senior Ayatollah in Iraq today, Grand Ayatollah Ali Sistani, holds a more nuanced view given his forays into political issues, but clearly the notion of guardianship of the jurist does not play a large role in his theories of Islamic jurisprudence given how infrequently he refers to it. See, e.g., The 
Given the extra-legal nature of the marjaiyya and the deep respect the Iraqi Shi'a afford their leaders, ${ }^{68}$ deference to non-legal forms of authority is inevitable. This fact alone renders Iraq quite unique among Islamic nations. Professor Lombardi, for example, admirably has shown how the Supreme Constitutional Court of Egypt has adopted novel and modernist interpretations of sharia in certain instances. ${ }^{69}$ It has done this in light of a 1980 amendment to Article 2 of the Egyptian Constitution, which, according to that court, requires that all Egyptian legislation prospective to the amendment be in conformity with the "principles" (mabadi) of shari'a.70 Professor Lombardi aptly notes that the traditional centers of learning in Egypt, most prominently the Azhar of Cairo, have lost their independence and a great deal of popular prestige, thereby enabling the state's judicial authorities to assume the role of jurists and to develop shari'a on their own. ${ }^{71}$ A similar approach is absolutely impossible in Iraq, however. The marja iyya remains a powerful and legitimate social force, and no judicial body could retain an ounce of credibility among the dominant Iraqi Shi'a by arrogating to itself the right to reinterpret shari'a. The exertion of effort to deduce Islamic rules from the primary sources, known as ijtihad, belongs exclusively to the marja'iyya.

\section{B. Disregard of Iraq's Context in Current Literature}

Nevertheless, the academic literature seems focused, either explicitly or implicitly, on inapposite comparisons to nations such as Egypt with vastly different traditions and developments. For example, Professor Stilt specifically contrasts the Egyptian context with that of Iraq, suggesting that many of the same difficulties concerning the role of Islamic law in Egypt apply to Iraq. ${ }^{72}$ She compares the Supreme Constitutional Court interpretation of Article 2 to a provision of similar importance in Iraq's Transitional Administrative Law (which functioned effectively as an interim constitution) respecting conformity of legislation with those immutable tenets

Official Website of Grand Ayatollah al-Uzma Seyyid Ali al-Sistani, www.sistani.org (last visited Feb. 21, 2007) (discussing hundreds of Islamic rules and making only one obscure reference to the notion of wilayat al-faqih).

68 See, e.g., PACKER, supra note 1, at 213 (indicating deep reverence within Iraq to one of its most senior leaders, Ayatollah Ali Sistani).

69 Clark B. Lombardi, State Law as Islamic LaW in Modern EgyPT: The Incorporation of THE SHARI'A INTO EGYPTIAN CONSTITUTIONAL LAW 201-58 (2006).

${ }^{70}$ Id. at 4-5.

71 Id. at 67-69.

72 See generally Kristen Stilt, Islamic Law and the Making and Remaking of the Iraqi Legal System, 36 GEO. WASH. INT'L L. REV. 695 (2004). 
(thawabit) of Islam on which there is consensus. She then quotes a respected and influential Egyptian scholar as to what the clause might mean. ${ }^{73}$

Stilt recognizes that this opinion is only one of many, but she fails to account for the substantial irrelevancy of her position among the dominant Shi'a and the inherent illegitimacy of any judicial interpretation of shari'a within Iraq.

Stilt's misguided assumptions continue in her extensive discussion of family law in Egypt and a case concerning the interpretation of Article 2 involving alleged apostasy and a resulting obligatory divorce. ${ }^{74}$ The case is complex and Stilt distills it very admirably, but in a way that makes clear its entire inapplicability to Iraq. Most tellingly, the Egyptian court addresses whether the defendant is permitted to perform ijtihad in the context of his work. ${ }^{75}$ Nothing could be further removed from the realm of possibility in Iraq than the prospect of state organs dictating the constitution of the marja'iyya, which is what a determination on the right of ijtihad essentially would entail.

This is not to suggest that Professor Stilt's work is entirely without purpose. She relates the Egyptian context admirably, and she firmly understands parts of Iraq's Sunni Arab dominated historical legal tradition. Moreover, it is quite possible that particular parts of the Egyptian example potentially could apply to Iraq, notwithstanding the vastly different contexts. Nevertheless, Stilt's failure to address the specific characteristics of Iraqi Shi'ism or their ramifications means that an important element of any comparative effort is missing.

While not making as thorough an analogy as Stilt, Noah Feldman displays similar biases in the crucial area of family law. ${ }^{76} \mathrm{He}$ argues, for example, that a resolution introduced by the GC to repeal the Personal Status Law and replace it with an uncodified form of Shari'a was a "restoration of judicial flexibility." 77 It might well be in a nation such as Egypt. However, while Feldman's erudite analysis accurately identifies the motivation behind the enactment of the resolution, his description of it as a restoration of "judicial flexibility" is entirely wrong in the Iraqi context. In order for "judicial" flexibility to exist, judges appointed and controlled by

73 Id. at 744. Professor Stilt's Article was written prior to the issuance of the current Constitution, but Article 2 of the present Iraq Constitution contains a provision somewhat similar to that of the Transitional Administrative Law. IRAQ CONST. art. 2 (2005).

74 Stilt, supra note 72 , at $735-40$.

${ }^{75} \mathrm{Id}$. at $737-38$

76 NOAH FELDMAN, WHAT WE OWE IRAQ: WAR AND ETHICS OF NATION BUILDING 108-11 (2004).

${ }^{77} I d$. at $109 \cdot 10$. 
state institutions and state processes would need to have the ability to interpret and apply shari'a. This could not happen in Iraq. That function, at least for the dominant Shi'a, is juristic and not judicial.

Feldman's work on the dangers of externally imposing constitutional norms in developing nations makes similar erroneous assumptions to the extent they are supposed to apply to Iraq. ${ }^{78}$ For example, his focus on the role of Shari'a in the development of constitutional provisions is misplaced. ${ }^{79}$ The issue in Iraq is not so much about the formal imposition of inequality within the constitution, or, indeed, broader legislation through the incorporation of Islam or Islamic norms. Rather, the issue is the absence of state oversight in areas in which Shari'a is expected to dominate, whether they be regulation of currency houses or rights in marriage and divorce. ${ }^{80}$ The best example lies in the current Personal Status Law, which formalizes inequality between the genders along the lines of the traditional Shari'a. ${ }^{81}$ Despite its superficial similarity to traditionalist notions, Shi'i Islamists find its provisions entirely unacceptable because they give courts the power to apply rules that are the proper province of the marja'iyya. ${ }^{82}$

Feldman's ultimate conclusion, therefore, that constitutions should be a pact among domestic political elites in order to ensure their implementation and enforcement within the state in question, may well be true. ${ }^{83}$ However, in the context of Iraq, this conclusion should be qualified by the fact that one important element of power, the marja iyya, is not-and cannot in its current form-function as a political institution, and the broader body politic has reacted to this through biases against the exercise of state power in particular realms. In Iraq, therefore, the exercise of democracy so promoted by senior elements of the marja iyya does not, as Feldman posits, guarantee Islam a continued role in the constitutional order, ${ }^{84}$ but rather entrenches Islam's power and the power of the institution acting in its name. In this way, Islam maintains aspects of the social order independently of the state and its constituent organs.

\footnotetext{
${ }^{78}$ Noah Feldman, Imposed Constitutionalism, 37 CONN. L. REV. 857 (2005).

${ }^{79}$ Id. at $887-89$.

80 See infra Part V.

${ }^{81} I d$.

${ }^{82} I d$.

${ }^{83}$ Feldman, supra note 78 , at 885.89.

${ }^{84}$ Id.
} 


\section{Alternative APPROACHES IN THE DEVELOPMENT OF LEGAL AND ECONOMIC ORDER}

In the realm of financial regulation, Iraq will most likely be unable to sustain the practice of abdicating state oversight in favor of alternative forms of authority, due to the increasingly global nature of commerce and the fluidity of cash across national boundaries. Moreover, a patchwork of regulation directed exclusively at "sinful" institutions is not sensible in the contemporary era. Given modern commercial realities, state-administered and enforced regulation must be designed to achieve broader social and economic objectives, rather than being directed exclusively at institutions that violate religiously inspired norms. Indeed, the argument that interest is an exploitative form of commercial gain does not withstand scrutiny. Iraq's profound isolation over the past two decades has not permitted its Islamists to scrutinize "Islamic" forms of commerce more closely. If they did, they would realize that the ban is routinely circumvented through the creation of elaborate artifice that mimics interest in all but name. ${ }^{85}$

At the same time, ignoring the Iraqi perspective and imperially imposing legislation notwithstanding GC objections has not led to salutary results for the CPA. Iraq has not passed any money laundering bill with the genuine possibility of enforcement at the necessary levels. As Iraq continues its evolution and development, some ideas might help guide its transition in a manner that simultaneously presupposes an organic and gradual change in underlying biases regarding the exercise of political authority in the contemporary state, and pays heed to the traditionalist assumptions reflected in the objections to Order $93 .{ }^{86}$ It is important to note that these ideas apply rather narrowly in areas such as financial regulation, where the body politic accepts the idea of state oversight, but seeks limited exemptions and alternative forms of control for certain actors. A considerably greater problem exists in areas such as family law, where the state's role is assumed to be considerably more circumscribed.

The traditional Islamic bans on particular forms of commercial risk and exploitation should be interpreted more functionally, as they have been by key former forces within the marja iyya, ${ }^{87}$ to address particular issues of concern within the Muslim community respecting commercial development, rather than erecting formal bans on vital practices such as the taking of

${ }^{85}$ See, e.g., Hamoudi, Muhammad's Social Justice, supra note 56, at Part III.B.

86 I do not suggest that such evolution is imminent; indeed, given the turbulent and volatile situation existing in Iraq today, significant time is likely to pass before a sensible civil discourse can begin on the development of legal order. Irrespective of the particular time frame, however, it seems inevitable that a time will come when Iraq will need to address these questions.

87 See Hamoudi, You Say You Want a Revolution, supra note 62, at Part III (discussing the jurisprudence of Sadr and its attempt to achieve a form of revolutionary economic functionalism in Islamic societies). 
interest or the purchase of insurance, which by necessity will be merely circumvented. ${ }^{88}$ There are several advantages to this approach, but a vital one is demonstrated precisely by the problem articulated with respect to Order 93; some of my colleagues viewed interest not only as sinful, but also as exploitative. Institutions that take interest are therefore seen as heartless and in need of regulation. My colleagues frequently quoted verses of the Qur'an which in strident terms ban a largely undefined practice known as riba, assumed to be the taking of usury, as exploitation akin to thievery. ${ }^{89}$ The reality is that whatever exploitation lies in debt-based transactions also exists in its analogues in Islamic finance. ${ }^{90} \mathrm{~A}$ more functional approach that reformulates the riba prohibition to address exploitative and unconscionable practices would allow Muslim communities to direct their concerns in more appropriate directions. Given a functional shari'a hermeneutic that defined riba to encompass truly objectionable practices, the state regulatory system could operate sensibly. At that point, subjection of commercial actors engaged in the practice of the newly defined riba to increased scrutiny would be more defensible.

The consideration of Islamic ideals and principles also would assist efforts to extend authority over currency exchangers to control money laundering. Underlying much of the concern driving the objections to Order 93 was the fact that the government was, by American fiat, going to place family enterprises on the same level as banks and treat them as such, while ignoring more traditionalist forms of authority in line with shari'a principles and cultural norms. A more organic process driven by Iraqis would help allay concerns about American dominance. A functionally reformed Islamic commercial doctrine would help demonstrate that the regulations do not thwart the central Quranic goals, but in fact further them. State regulations that appear to support Islamic aims might relax the reflexive deference to traditional non-state forms of authority in areas such as finance, where the legitimacy of some level of state intervention is already widely accepted.

\section{The Problem of Personal Status Law}

This Article largely focuses on one aspect of financial regulation and the role of distinct biases in its implementation. It is important to note, however, that the conflicting biases respecting the role of alternative forms of authority appear in other contexts as well-in some cases in a more dramatic and significant fashion. The most obvious example is the repeated attempts by

88 Hamoudi, Muhammad's Social Justice, supra note 56; Haider Ala Hamoudi, Jurisprudential Schizophrenia: On Form and Function in Islamic Finance, 7 U. CHI. J. INT'L L. (forthcoming 2007).

89 See The Qur'an 275-76.

90 Hamoudi, Muhammad's Social Justice, supra note 56. 
Shi'i Islamists to repeal in large part the Personal Status Law of 1959 and replace it with the rules of Shari'a. ${ }^{91}$

In keeping with the practice of most Middle Eastern nations, ${ }^{92}$ Iraq's Personal Status Law, which addresses matters such as marriage, divorce, child custody, and inheritance, largely reflects traditional understandings of Shari'a. ${ }^{93}$ Thus, it contains patently discriminatory provisions against women, including inheritance rights equivalent to half of those of similarly situated men, ${ }^{94}$ limited separation opportunities as compared with divorce at will for men ${ }^{95}$ and tolerance of polygamy for men, but not for women. ${ }^{96}$ Nevertheless, it is a pastiche of various Islamic rules from different Muslim schools of thought along with particular, modest reforms that by and large render it more favorable to women than the traditional schools of thought would normally accept. ${ }^{97}$ For example, the Law sets the age of marriage at eighteen years, in contravention of the traditional shari'a. ${ }^{98}$ It also grants

\footnotetext{
91 For an excellent description of one such effort that ultimately failed, see Stilt, supra note 72, at 748-55. The current Constitution also contemplates the enactment of legislation of this sort. IRAQ CONST. art. 41 (as published in the Iraqi Gazette, on file with author). More than one reference in the academic literature refers, mistakenly, to this Article as Article 39, apparently based on a reference to a translation of the Constitution contained in an MSNBC website. See Joseph Khawam, Note, A World of Lessons: The Iraqi Constitutional Experiment in Comparative Perspective, 37 Colum. HuM. RTS. L. REV. 717, 750 (2006) (citations omitted); Vanessa Jimenez, Iraq's Constitutional Process: Challenges and the Road Ahead, 13 HUM. RTS. BRIEF 21, 23-24 (2005) (citing http://www.msnbc.msn.com/id/9719734/).
}

92 See generally BERNARD G. WEISS, THE SPIRIT OF ISLAMIC LAW 688 (1998).

93 See generally Qanun Al Ahwal Al-Shaksiya Raqm 188 li Sanat 1959 wa Ta'deelatihi, [Law 188/1959 of Personal Status, together with its amendments] (7th ed. 2000) [hereinafter Personal Status Law]. Professor Stilt provides a thorough and engaging account of the development of Iraq's Personal Status Law in her article on the role of Islamic law in Iraq's legal system. Stilt, supra note 72 , at $748 \cdot 55$.

94 Personal Status Law, supra note 93, at arts. 86-90.

95 Id. at arts. 34-46.

96 Id. at art. 3.

${ }_{97}$ See Stilt, supra note 72 , at 748-55.

98 Personal Status Law, supra note 93, at art. 7(1). Within the four major schools of Sunni Islam, the classical shari'a permits fathers and paternal grandfathers to enter into marriage contracts on behalf of minor children that are binding upon the children. JOHN ESPOSITO WITH NATANA J. DELONG-BAS, WOMEN IN MUSLIM FAMILY LAW 16-17 (2d ed. 2001). Shi'i Islam is more liberal in theory, in that it permits children to repudiate the contracted marriage when they are, using the traditional Shari'a's terminology, mature, or baligh. See Website of Grand Ayatullah Sistani, Islamic Laws, Conditions of Pronouncing Nikah, Rule 2384, http://www.sistani.org/html/eng (follow "Islamic laws" hyperlink, select "marriage" from first pull-down menu, select "Conditions of Pronouncing Nikah" from second pull-down menu). However, given that a child under the traditional shari'a is baligh at the onset of puberty, which is often set at nine in the case of girls, 
women expanded rights in child custody disputes, and requires men to be responsible financially for children after divorce or separation. ${ }^{99}$

This context is important and deeply misunderstood.100 Iraq's Personal Status Law is hardly liberal towards women by any reasonable global measure. It is blatantly discriminatory and profoundly anti-modern. Much attention has been given to the effect that repeal of the law, and the replacement of it with the traditional Shari'a, might have on women's rights. However, given the state of the existing Personal Status Law, the reversal would not be nearly as significant as the critics suggest. ${ }^{101}$ Some significant changes would no doubt result, perhaps most important among them those concerning child marriage and rights of custody. For the most part, however,

the distinction is not as significant as could be imagined. Islamic Laws, Rule 2419, id. at Women with whom Matrimony is Haraam (select "Women with whom Matrimony is Haraam" from second pull-down menu) (requiring that a person who was contractually married to a girl to refrain from sexual activity with her until she had reached the age of nine).

99 Personal Status Law, supra note 93, at arts. 57, 59. The traditional Shari'a rules concerning child custody are complex and vary by school of thought and even by jurist within each school of thought, but generally tend to favor mothers (so long as they do not remarry) until the onset of puberty, at which point the father tends to have sole custody rights. See, e.g., JAMAL J. NASIR, The IsLAMIC LAW OF PERSONAL STATUS 156-72 (3d ed. 2002); LomBARDI, supra note 69, at 203-04 (discussing Sunni rules).

100 To his credit, Feldman recognizes this in his own work, though he seems to minimize the effect of the expected change on the rights of women to a greater extent than might be justifiable. FELDMAN, supra note 76, at 109, 140 n.31.

101 For a characteristic, alarmist position on the rights of women in Iraq and the changes that any amendment to the Personal Status Law might bring, see Maureen Dowd, Reformer Without Results, N.Y. TIMES, Aug. 13, 2005, at A11. Writing in relation to a proposed constitutional provision similar in form to GC Resolution 137, Dowd suggests that the civil courts that govern personal status affairs might be changed into religious courts applying Shari'a which might, in her words "legitimize polygamy, honor killings, stonings and public beheadings of women charged with adultery, and divorce by 'talaq' where all a husband has to do is declare, 'I divorce thee,' three times." Id. There is not a single correct factual assertion in this quote, and much of it is more characteristic of regrettable, reflexive bigotry than any sort of analysis. Nothing in sharia sanctions extrajudicial murders of the sort that constitute "honor killings." The punishment for adultery under Shari'a requires more than a simple "charge"; it requires proof in the form of numerous witnesses to the act. JOSEPH SCHACHT, AN INTRODUCTION TO ISLAMIC LAW 177 (1965). More importantly, these transgressions, along with any accompanying punishments, would have no relevance of any kind to the Personal Status Law, but instead to the Penal Code, which no political party seeks to amend. The word "talaq" reflects a right to divorce that, like polygamy, is already available at will to men in the Personal Status Law. Personal Status Law, supra note 93, at art. 34. Shi' Islam does not recognize the triple divorce at all. DAVID PEARL, MUSLIM FAMILY LAW 280 (1998). While the role of Shari'a in the Iraqi legal system is an important one, Dowd's ridiculous, cartoonish portrayals of crazed turbaned mullahs publicly beheading lewd women does little to advance the debate. See also Vivian Stromberg, Protecting Women's Rights in Iraq, DET. FREE PRESS, Aug. 10, 2005; Brooke D. Rodgers-Miller, Seminar Papers on Women and Islamic Law: Out of Jahiliyya: Historic and Modern Incarnations of Polygamy in the Islamic World, 11 WM. \& MARY J. WOMEN \& L. 541, 560-61 (2005) (suggesting that the introduction of Shari'a would "legalize polygamy"); Pamela Constable, Iraqi Women Fear Push for Sharia Law, CHI. TRIB. Jan. 21, 2004, at A2; Charles Clover \& Nicolas Pelham, Iraqi Plan for Shari'a Law a 'Sop' to Clerics, Women Say, Fin. Times (London), Jan. 15, 2004, at A11. 
the Personal Status Law was already more a reflection of traditional shari'a rules than a significant departure from it.

Seen in this light, continuing efforts by conservative Shi'i politicians to repeal the Personal Status Law and replace it with Shari'a do not seek a change in particular rules. Rather, they call for an alternative system of authority in the personal status realm under which, at least for the dominant Shi'a, institutions operating entirely independently of the state, namely the marja'iyya, would play the primary rulemaking role. The jurists would then have a free hand in developing the rules pursuant to which personal status cases were adjudicated.

Moreover, the ability of non-state elements to adjudicate and enforce decisions would be noticeably enhanced. A clan, for example, cannot sensibly convene an ad hoc tribunal to determine rights and obligations under the Personal Status Law. The Personal Status Law was issued by state organs and is subject to state institutional administration. Shari'a, by contrast, is God's law, derived under the principles of Shi'ism by a non-state institution, the marjaiyya. It is not immediately obvious why a state-appointed judge would be better suited to administer it than a tribunal headed by a student of one of Najaf's most respected scholars who claims no state allegiance. This is particularly true in light of the fact that, as Feldman properly notes, the motivation behind the move to repeal the Personal Status Law was to enhance local, sectarian power at the expense of national authority. ${ }^{102} \mathrm{Ad}$ hoc tribunals and clan-oriented justice organized in connection with juristic determinations of Shari'a help to achieve precisely that.

As with financial regulation, this outcome is not wholly implausible. For example, in clear contravention of the Personal Status Law, which was in effect at the time, my Iraqi mother-in-law was married at the age of fifteen. Familial preferences, clan determinations, and juristic rules were simply more important forms of authority than the institutions responsible for implementing and enforcing the legal code. Nevertheless, it is unlikely that this type of exercise of alternative non-state authority is capable of sustaining itself in the long run. One problem would be that rights supposedly guaranteed by the Iraqi State could be placed in serious jeopardy if it were to abdicate its role in matters of personal status, especially given the blatantly discriminatory elements of the traditional Shari'a. ${ }^{103}$

More critically in the Iraqi context, however, is the threat that reliance on such forms of extra-legal authority presents to the long-term viability of the state. By most accounts, Iraq's central contemporary problem is that some forms of authority that are not subject to state oversight or control already pose substantial threats to Iraq's survival as a political entity. In

102 FELDMAN, supra note 76 , at 109.

${ }^{103}$ See supra notes 85-92 and accompanying text. 
many cases, these are militias jockeying for political power, or tribes battling with militias or terrorist groups, but it seems clear that part of Iraq's current political chaos stems from the application of authority by non-State elements. ${ }^{104}$ These difficulties supersede well-publicized sectarian tensions. Basra, for example, is experiencing unusually high levels of intra-Shi'i violence. ${ }^{105}$ While most reports on the subject routinely discuss the problem of militias in the context of political wrangling, it is important to note that the social and ideological context in which the militias arise is one in which the extra-legal exercise of authority is not only tolerated, but actively encouraged.

As with Order 93, the solution to easing Iraq's transition to a modern nation-state lies less with the imposition of an alternative legal structure that Iraqis are likely to find entirely unacceptable and more with solutions that incorporate the biases and presuppositions of Iraqis regarding the nature of political rule. In the context of Order 93, I proposed a new understanding of Islamic doctrine that realizes the functional commercial aims articulated by former prominent members of the marjaiyya. ${ }^{106}$ This type of reexamination would allow Iraqis to understand the functional regulation of the State to be in furtherance of, rather than in derogation of, Islamic norms and understandings. Iraqis might then support the extension of that state regulation to actors they had not thought should be subject to it.

This solution is partial and incomplete, as the personal status example makes clear. Unlike financial regulation, where the legitimacy and necessity of state administered regulation is accepted at least in part, those advocating the repeal of the Personal Status Law seek virtually entire domination of the field by juristic authorities. Any state involvement in rulemaking is, to these advocates, the precise problem they seek to address.

The solution to this dilemma is nuanced and goes to the intractable heart of the Iraqi problem concerning competing forms of authority in the state. I leave the solution to a later paper, one which explores in greater depth the structure of the marja'iyya, the nature of its rulemaking, and the effect this has on the role of Shari'a in the Iraqi legal system. This paper will borrow to some extent from the ideas of Professor An-Naim, but it will contextualize them to the Iraqi situation. Suffice it to say, however, the only way to address this problem adequately is through the robust assertion of exclusive lawmaking, adjudicative, and enforcement power by the State, with the

\footnotetext{
${ }_{104}$ See, e.g., Nelson Hernandez, Iraq's Premier Sets State of Emergency For Southern City; Maliki Cites Rising Violence in Basra, WASH. POST, June 1, 2006, at A14; John Ward Anderson, Iraqi Tribes Strike Back at Insurgents; In Turbulent Areas, Zarqawi's Fighters Are Target of Leaders and a New Militia, WASH. PosT, Mar. 7, 2006, at A12.
}

${ }^{105}$ Hernandez, supra note 104.

106 See supra note 62 and accompanying text. 
[Vol. 16:523

marja'iyya playing a vital normative role in influencing legislative developments and personal behavior and conduct through its broad, admirable, pluralistic tradition. In this way, the highly respected marja'iyya retains its premier place in Iraqi society while the State controls forms of authority that involve coercive rulemaking, adjudication, and enforcement. If Iraq is to remain a viable state rather than a collection of permanently warring clans, tribes, sects, and their associated militias and jurists, there is no alternative. 